\title{
METALS IN SEDIMENT AND PHRAGMITES AUSTRALIS (COMMON REED) FROM TISZA RIVER, SERBIA
}

\author{
ŠTRBAC, S. ${ }^{1}{ }^{*}$ - ŠAJNOVIĆ, A. ${ }^{2}$ - KAŠANIN GRUBIN, M. $^{1}$ - VASIĆ, N. ${ }^{3}$ - DOJČINOVIĆ, \\ B. $^{4}$ - SIMONOVIĆ, P. $^{5}$ - JOVANČIĆEVIĆ, B. ${ }^{4}$ \\ ${ }^{1}$ Faculty of Environmental Protection, Educons University, \\ Sremska Kamenica 21208, Serbia,+381214893676, strbacsn@eunet.rs \\ ${ }^{2}$ Center of Chemistry, Institute of Chemistry, Technology and Metallurgy, University of \\ Belgrade, \\ Belgrade 11000, Serbia \\ ${ }^{3}$ Faculty of Mining and Geology, University of Belgrade, \\ Belgrade 11000, Serbia \\ ${ }^{4}$ Faculty of Chemistry, University of Belgrade, \\ Belgrade 11000, Serbia \\ ${ }^{5}$ Faculty of Biology, University of Belgrade, \\ Belgrade 11000, Serbia \\ *Corresponding author \\ e-mail:strbacsn@eunet.rs \\ (Received $28^{\text {th }}$ Jan 2013; accepted $22^{\text {nd }}$ July 2014)
}

\begin{abstract}
In this study the concentrations of metals were investigated in Phragmites australis (Cav.) Trin. eh Steud. 1841 and sediment samples from the bed of the River Tisza in Serbia. Al, As, B, Cd, Co, Cr, $\mathrm{Cu}, \mathrm{Fe}, \mathrm{Hg}, \mathrm{Mn}, \mathrm{Ni}, \mathrm{Pb}, \mathrm{Se}, \mathrm{Sr}$ and $\mathrm{Zn}$ levels were analyzed using inductively coupled plasma - optical emission spectrometry. The sediment samples contained elevated concentrations of cadmium, chromium, copper, nickel and zinc. The increased concentration of these metals had no significant effect on wildlife of the river Tisza as the determined concentrations of the metals tested in the comon reed do not exceed the threshold of phytotoxicity. The research proved a strong positive correlation between the concentrations of metals in the sediment and all common reed organs (rhizome, stem and leave). Accumulated metals in the common reed are not distributed evenly, but there are target organs for bioaccumulation. Concentrations in belowground organs were usually higher than aboveground organs, and the general decreasing trend of element content was rhizome $>$ leaves $>$ stems.
\end{abstract}

Keywords: metals, sediments, plant organs, River Tisza.

\section{Introduction}

Knowing the mechanism of accumulation, distribution and metabolism of metals in aquatic macrophytes is of great ecological, scientific and practical importance (Kastori et al., 1997). From the environmental point of view, the importance is reflected in the fact that aquatic macrophytes could be used as biological indicators of pollution (Pall et al., 1996; Ravera, 2001; Balanson and Mal, 2005; Borišev and Stanković, 2006; Bonanno, 2011). Increased concentration of an element accumulated in the organs of a plant indicates an increasing load caused by this element in the nearby habitat, so the data on the concentration of certain chemical elements in different parts of the plant tissue can be used as indicators of chemical influences on natural resources (Gerloff and Krombholz, 1966; Pajević et al., 2002). Significant bioconcentration of certain elements 
in plant tissue occurs as a result of the lack of regulatory mechanisms concerning the uptake of metals, particularly when the concentration of an element in the environment is markedly increased (Stanković et al., 2000; Pajević et al., 2002). In order to assess the effect of excessive metal concentration in natural resources, it is necessary to assess the correct amount of nutrients needed for the metabolism of plants, so that the increased accumulation of certain elements in the organs could be attributed to their increased concentration in the surrounding environment (Gerloff and Krombholz, 1966; Pajević et al., 2002). The value of macrophytes as bioindicators in river systems is reflected in the fact that they always stay in one place, they are usually abundant, their sampling is easy, and taxonomic affiliation can be easily determined (Olivares-Rieunont et al., 2007). Due to the fixed positions of the rooted submerged and floating hydrophytes, as well as emersal species, they have a role as bioaccumulators and biofilters, which is manifested mainly in shallow waters, in coastal areas of rivers, canals and lakes, as well as in parts of the river where the water flows more slowly (Westlake, 1975). Different types of aquatic macrophytes adopt and accumulate metals with different intensity. The differences are especially noticeable in species that grow in habitats that are anthropogenic or naturally rich in polluted metals (Pall et al., 1996; Ravera, 2001; Balanson and Mal, 2005; Borišev and Stanković, 2006).

The accumulation of metals in tissues and cell compartments of the same species also differs, because the plants can attain metals through different organs (root, rhizome, leaf) (Welsh and Denny, 1980; Ward, 1987; Bishop and DeWaters, 1988; Levine et al., 1990). Metals, which are particularly non-essential in the roots of aquatic macrophytes, accumulate more intensively than in the aboveground plant parts. Rooted aquatic plants have fibrinous root system with large contact area (Wang et al., 1997). When they enter the root system, nutrients are transported through the plant and placed into cells. Transport within the body of a plant is done by the water flow through xylem or cytoplasmic fibers, and is strictly conditioned by environmental factors, such as temperature, humidity, light intensity and light quality. Toxic components are then deposited in the vacuoles, leaves, etc. (Agbaba et al., 2008). The intensity of adoption depends not only on the type of metal, but also of their involvement in biochemical reactions, while mobility, in connection with the distribution of metals in plants, often depends on their ability to form chelate complexes together with the components of the xylem sap (Kastori et al., 1997).

In aquatic ecosystems, rooted macrophytes such as reeds $P$. australis (Cav.) Trin. et Steud. 1841 are under greater influence from metals coming from sediments than those coming from the water, and therefore bioaccumulation is greater if the sediment contains higher concentration of metals (Zwolsman et al., 1993). Numerous studies have pointed to a positive correlation between the metals in the sediment and various reed organs (Peverly et al., 1995; Wang et al., 1997; Bonano and Lo Giudice, 2010; Bonano, 2011). By studying the concentration of microelements in the rhizome, root, stem and leaf of $P$. australis in Italy, Bonanno (2011) found a strong positive correlation between the elements identified in plants and sediments, and he also found out that the metals remain mostly in reed rhizome. Peverly et al. (1995) point out that the reed rhizome plays the role of the filter, thus protecting the above ground parts from increased metal concentrations (Peverly et al., 1995). Wang et al. (1997) also found that heavy metals are accumulated mainly in the roots with little translocation to the aboveground organs (Wang et al., 1997). As a good bioacumulator of chemical elements, (Duman et al., 2007; Bragato et al., 2009), the common reed has found a wide 
application in the treatment of municipal and industrial wastewater loaded with metals (Bragato et al., 2009; Lesage et al., 2007; Vymazal et al., 2007).

In this paper $\mathrm{Al}, \mathrm{As}, \mathrm{Cd}, \mathrm{Co}, \mathrm{Cr}, \mathrm{Cu}, \mathrm{Fe}, \mathrm{Hg}, \mathrm{Mn}, \mathrm{Ni}, \mathrm{Pb}, \mathrm{Se}, \mathrm{Sr}$ and $\mathrm{Zn}$ levels are determined in the rhizome, stem and leaves of the common reed and sediment samples from the bed of the Tisza River. Therefore, the objectives of this paper are: i) to give a pilot screening of metals content in aquatic plants from various sites on the Tisza River, ii) to provide a preliminary insight into the bioaccumulation patterns, and iii) to determine the degree of contamination of the Tisza River.

\section{Materials and Methods}

\section{Study area}

This study analyzed metals in P. australis (Cav.) Trin. et Steud. 1841 and the sediment from the Tisza River in Serbia $\left(45^{\circ} 08^{\prime} 04.45^{\prime \prime}-46^{\circ} 04^{\prime} 06.31^{\prime \prime} \mathrm{N}, 20^{\circ} 16^{\prime} 54.09^{\prime \prime}-\right.$ $\left.20^{\circ} 04^{\prime} 07.52^{\prime \prime} \mathrm{E}\right)$. The basin of the River Tisza is one of the largest natural river systems in southeastern Europe, and it is located almost exactly in the geographical centre of Europe and crosses the new boundaries of the European Union. The River Tisza originates in the Zakarpatian Mountains in western Ukraine and flows into the Danube by Slankamen (Serbia). With respect to its length of $966 \mathrm{~km}$, the River Tisza forms the largest tributary of the Danube River. Anthropogenic influences cause permanent pollution from communal, industrial or agricultural activities. In Serbia the waste water from factories and municipal sewage discharges represent sources of inorganic pollution. In the past, the Tisza had suffered a large number of polluting accidents. The Tisza is an international river and, from its confluence with the Danube, the pollution is transmitted towards the Black Sea.

\section{Sample collection}

All plant material was sampled at four sites on the Tisza River in Serbia. The first sampling point (Fig. 1) was on the $3^{\text {rd }} \mathrm{km}$ of the river flow near the village Titel $\left(45^{\circ} 8 ' 20.44^{\prime \prime} \mathrm{N}-20^{\circ} 16^{\prime} 8.68^{\prime \prime} \mathrm{E}\right)$. The second and the third sampling points were on the $58^{\text {th }} \mathrm{km}$ and $72^{\text {th }} \mathrm{km}$ of the river flow near the city of Novi Bečej $\left(45^{\circ} 35^{\prime} 17.44^{\prime \prime} \mathrm{N}-\right.$ $\left.20^{\circ} 7^{\prime} 45.34^{\prime \prime} \mathrm{E}\right)$. The fourth sampling point was on the $153^{\text {rd }} \mathrm{km}$ of the river flow near the city of Kanjiža $\left(46^{\circ} 4^{\prime} 15.66^{\prime \prime} \mathrm{N}-20^{\circ} 3^{\prime} 59.79^{\prime \prime} \mathrm{E}\right)$. All marks $3^{\text {rd }} \mathrm{km}, 58^{\text {th }} \mathrm{km}, 72^{\text {th }} \mathrm{km}$ and $153^{\text {rd }} \mathrm{km}$ of the river flow refer to the upstream distance from the confluence with the Danube River.

In each sampling point, 30 samples of $P$. australis were collected within a $5 \times 2 \mathrm{~m}^{2}$ plot. All the plant species had the same habitat with an average height of $2 \mathrm{~m}$. Sampling of the plant material was conducted in areas bordering the river bank, and subject to periodic flooding. After collection, the plant samples were put in sealed plastic bags to avoid extraneous contamination. Climatically identical days were chosen in order to exclude the influence of weather conditions. The month of September was chosen because it coincides with the peak of the vegetative period of the common reed during which trace element concentrations generally show the highest values in the plant organs (Bonano, 2011).

Sediment samples were collected from 25 locations along the Tisza River on the territory of the Republic of Serbia (Figure 1) using a plastic corer. After sampling sediments were packed in polyethylene bags and transported to the laboratory. 


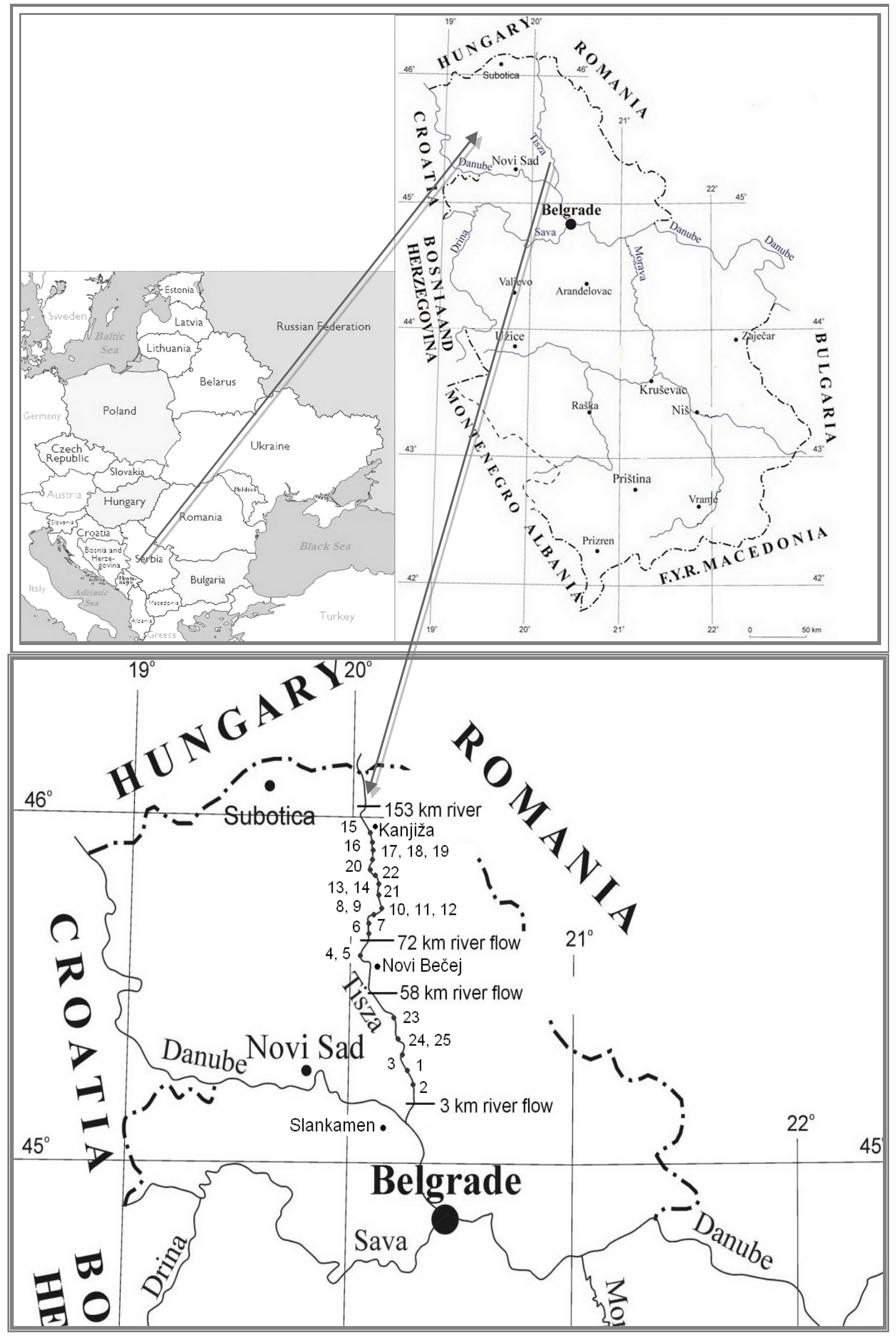

Figure 1. Study area. Four sites of plant samples marked with: $3^{\text {rd }} \mathrm{km}, 58^{\text {th }} \mathrm{km}, 72^{\text {th }} \mathrm{km}$ and $153^{\text {rd }} \mathrm{km}$ river flow. Twenty-five sites of sediment samples marked with numbers: 1-25. 


\section{Sample analysis}

Plant samples were preliminarily dissected into rhizomes, stems and leaves. In particular, stem samples were prepared by considering the whole stem. Rhizomes, stems and leaves from the same localities were homogenized in an electric blender and stored in plastic bags until analysis. To prepare analytical samples $0.5 \mathrm{~g}$ of samples were digested in a microwave digester (ETHOS 1, Advanced Microwave Digestion System, MILESTONE, Italy) using $7 \mathrm{ml}$ of $65 \% \mathrm{HNO}_{3}$ with $1 \mathrm{ml}$ of $30 \% \mathrm{H}_{2} \mathrm{O}_{2}$ and $1 \mathrm{ml} \mathrm{H}_{3} \mathrm{PO}_{4}$ and $0.5 \mathrm{ml} \mathrm{HF}$ of analytical reagent grade (Carlo Erba, Italy). After cooling to room temperature, digested samples were diluted with distilled water to a total volume of 25 $\mathrm{ml}$. All the plastics and glassware were washed in nitric acid for $15 \mathrm{~min}$ and rinsed with distilled water before use. High purity argon was used as inert gas. Analysis was performed by inductively-coupled plasma optical spectrometry (ICP/OES, Thermo Scientific iCAP 6500 Duo Instrument, Thermo Fisher Scientific, Cambridge, UK), and comprised assessment of the concentrations of 14 metals (Al, As, Cd, Co, Cr, Cu, Fe, $\mathrm{Hg}, \mathrm{Mn}, \mathrm{Ni}, \mathrm{Pb}, \mathrm{Se}, \mathrm{Sr}$, and $\mathrm{Zn}$ ). The following wavelength lines of the ICP-OES analysis were used: Al $167.079 \mathrm{~nm}$, As $189.042 \mathrm{~nm}$, Cd $228.802 \mathrm{~nm}$, Co $237.862 \mathrm{~nm}$, Cr 267.716 nm, Cu 224.700 nm, Fe 240.488 nm, Hg 184.930 nm, Mn 257.610 nm, Ni $231.604 \mathrm{~nm}, \mathrm{~Pb} 220.353 \mathrm{~nm}$, Se $206.279 \mathrm{~nm}$, Sr $421.552 \mathrm{~nm}, \mathrm{Zn} 202.548 \mathrm{~nm}$. All metals concentrations were expressed in $\mu \mathrm{g} / \mathrm{g}$.

In the laboratory the sediment samples were wet-sieved through a $63 \mu \mathrm{m}$ sieve. Drying was conducted at room temperature. The dried samples were pounded gently in a porcelain mortar and pestle to break up to the aggregates. The samples were then split into smaller aliquots by coning and quartering. Sediments underwent two stages of preparation consisting of drying and screening. Sediments were dried at $60^{\circ} \mathrm{C}$ to minimize loss of volatile elements (eg. $\mathrm{Hg}$ ). Samples were then handled, dried and screened in an area dedicated for these media to avoid contamination from more mineralized rock and core samples. Screening consists typically of two stages comprising extraction of the desired elements into a solution and element determination by instrumental analysis of the solution. Extraction was total to measure the total abundance of the elements from all minerals in the sample. Analysis was performed by ICP-MS.

\section{Data analysis}

\section{Bioconcentration Factor (BCF)}

The $B C F$ provides an index of the ability of the plant to accumulate the metal with respect to the metal concentration in the substrate. The $B C F$ was calculated using Equation 1. A larger ratio implies better phytoaccumulation capability.

$$
B C F=(\mathrm{P} / \mathrm{E})_{\mathrm{I}}
$$

Where ${ }_{i}$ denotes the metal concerned, $B C F$ is the dimensionless bioconcentration factor, P represents the element concentration in plant organs $(\mu \mathrm{g} / \mathrm{g}), \mathrm{E}$ represents the initial concentration in the sediment ( $\mu \mathrm{g} / \mathrm{g}$ dry mass) (Gakwavu et al., 2012). 


\section{Translocation ability (TA)}

The translocation ability was calculated by dividing the concentration of an element accumulated in the root by that accumulated in the shoots. $T A$ was calculated using Equation 2.

$$
\mathrm{TA}=(\mathrm{Ar} / \mathrm{As}) \mathrm{I}
$$

Where ${ }_{i}$ denotes the metal concerned, $T A$ is the translocation ability and is dimensionless, $A_{r}$ represents the amount of element accumulated in the roots $(\mu \mathrm{g} / \mathrm{g})$, and $\mathrm{A}_{\mathrm{s}}$ represents the amount of element accumulated in the shoots $(\mu \mathrm{g} / \mathrm{g})($ Gakwavu et al., 2012). $T A>1$ indicates that plants efficiently translocated metals between different organs (Baker et al., 1994).

\section{Statistical analysis}

The correlation of metal content between sediment and plant organs was tested by Pearson $r$ coefficient. A one-way ANOVA, followed by the Tukey post-hoc test analysis, used to ascertain whether metal concentrations were significantly different among various organs and various localities. Statistical confidence was set at $\alpha=0.05$. A statistical analysis of data was carried out using the software SPSS version 15.0 of Statistical Software Package (SPSS Inc. Chicago, USA).

\section{Results}

\section{Contents of metals in sediment}

Contents of metals (in $\mu \mathrm{g} / \mathrm{g}$ of dry mass) in the sediment of the Tisza River bed are given in Table 1. The greatest contents were found for Al, Fe and $\mathrm{Mn}$. The decline trend in the sediment is following: $\mathrm{Al}>\mathrm{Fe}>\mathrm{Mn}>\mathrm{Zn}>\mathrm{Sr}>\mathrm{Cr}>\mathrm{Cu}>\mathrm{Ni}>\mathrm{Pb}>\mathrm{Co}>\mathrm{As}>$ $\mathrm{Cd}>\mathrm{Se}>\mathrm{Hg}$.

The obtained concentrations of metals in the sediment of the Tizsa River were compared with Serbian Regulation of limit values pollutant substances into surface water, groundwater and sediments and the deadlines for their attaining (SRLVsS). Despite its source metal concentration varies in sediment samples with the $\%$ of organic matter (OM) and clay. Therefore, limit values should not be presented as a single value but should be calculated for each sample. This is also a part of the Serbian regulation. In assessing sediment quality limit values for the sediment were corrected according to the measured \% of OM and clay. Corrected thresholds were compared with the measured concentrations of metals in the investigated sediment. To correct limits of metal concentration depending on the \% of clay and $\mathrm{OM}$ in the investigated sediment following correction formula was used (SRLVsS):

$$
\mathrm{GVK}=\mathrm{GVST} *(\mathrm{~A}+\mathrm{B} * \% \text { clay }+\mathrm{V} * \% \mathrm{OM} / \mathrm{A}+\mathrm{B} * 25+\mathrm{V} * 10)
$$

where: GVK - corrected threshold for a sediment when the \% of clay and OM are considered; GVST - limit values for standard sediment with $25 \%$ clay and $10 \% \mathrm{OM}$ 
(Table 2); \% clay -mineral fractions $<2 \mu \mathrm{m}$ in the examined sediment expressed in percentage of the dry weight; \% OM - measured OM content in the investigated sediment expressed in percentage of the dry weight and $\mathrm{A}, \mathrm{B} \mathrm{i} \mathrm{V}$ - constants depending on the type of metal (Table 3) (SRLVsS).

Table 1. Metal concentrations (Al, $\mathrm{As}, \mathrm{Cd}$, Co, $\mathrm{Cr}, \mathrm{Cu}, \mathrm{Fe}, \mathrm{Hg}, \mathrm{Mn}, \mathrm{Ni}, \mathrm{Pb}, \mathrm{Se}, \mathrm{Sr}$, $\mathrm{Zn}$ ) in sediments (in $\mu \mathrm{g} / \mathrm{g}$ of dry mass).

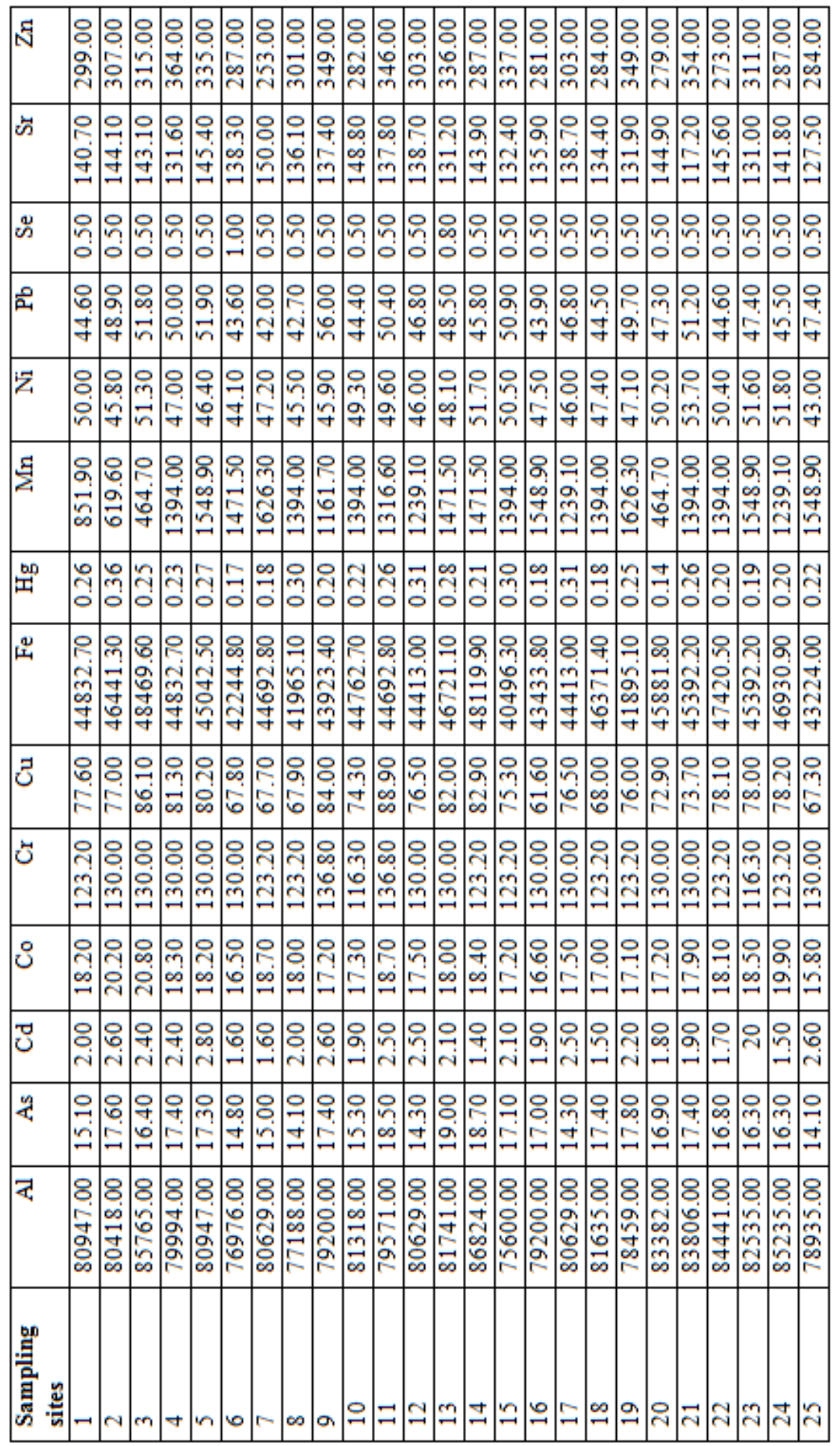


Table 2. Limit values for standard sediment with 25\% clay and 10\% OM (SRLVSS).

\begin{tabular}{|l|r|r|r|}
\hline Substance & \multicolumn{1}{|c|}{$\begin{array}{c}\text { LV - limit } \\
\text { values }\end{array}$} & $\begin{array}{c}\text { MLC - maximum legal } \\
\text { concentration }\end{array}$ & $\begin{array}{c}\text { RV - remediation } \\
\text { values }\end{array}$ \\
\hline Metals (in $\mu \mathrm{g} / \mathrm{g}$ DW) & \multicolumn{3}{|c|}{} \\
\hline Arsenic & 29.00 & 42.00 & 55.00 \\
\hline Cadmium & 0.80 & 6.40 & 12.00 \\
\hline Chromium & 100.00 & 240.00 & 380.00 \\
\hline Copper & 36.00 & 110.00 & 190.00 \\
\hline Mercury & 0.30 & 1.60 & 10.00 \\
\hline Lead & 85.00 & 310.00 & 530.00 \\
\hline Nickel & 35.00 & 44.00 & 210.00 \\
\hline Zinc & 140.00 & 430.00 & 72.00 \\
\hline
\end{tabular}

Table 3. Constants depending on the type of metal (SRLVSS).

\begin{tabular}{|l|r|r|r|}
\hline \multirow{2}{*}{ Substance } & \multicolumn{3}{|c|}{ Constants } \\
\cline { 2 - 4 } & $\mathrm{A}$ & $\mathrm{B}$ & $\mathrm{V}$ \\
\hline Metals (in $\mu \mathrm{g} / \mathrm{g}$ DW) & 15.00 & 0.40 & 0.40 \\
\hline Arsenic & 0.40 & 0.007 & 0.21 \\
\hline Cadmium & 50.00 & 2.00 & 0 \\
\hline Chromium & 15.00 & 0.60 & 0.60 \\
\hline Copper & 0.20 & 0.0034 & 0.0017 \\
\hline Mercury & 50.00 & 1.00 & 1 \\
\hline Lead & 10.00 & 1.00 & 0 \\
\hline Nickel & 50.00 & 3.00 & 1.50 \\
\hline Zinc & \multicolumn{3}{|c}{}
\end{tabular}

In Table 4 are given Serbian limit values and maximum legal concentrations for As, $\mathrm{Cd}, \mathrm{Cr}, \mathrm{Cu}, \mathrm{Hg}, \mathrm{Pb}, \mathrm{Ni}$ and $\mathrm{Zn}$.

\section{Contents of metals in common reed}

The contents of metals (in $\mu \mathrm{g} / \mathrm{g}$ of dry mass) in rhizome, stem and leaf of the common reed (Table 5) at different localities revealed a trend of decline as follows:

- In rhizome: $\mathrm{Fe}>\mathrm{Al}>\mathrm{Mn}>\mathrm{Zn}>\mathrm{Cr}>\mathrm{B}>\mathrm{Pb}>\mathrm{Ni}>\mathrm{Cu}>\mathrm{Sr}>\mathrm{As}>\mathrm{Se}>\mathrm{Cd}>$ $\mathrm{Co}>\mathrm{Hg}$;

- $\quad$ In stem: $\mathrm{Fe}:>\mathrm{Al}>\mathrm{Mn}>\mathrm{Zn}>\mathrm{Sr}>\mathrm{Pb}>\mathrm{Cr}>\mathrm{Cu}>\mathrm{Ni}>\mathrm{Se}>\mathrm{Co}>\mathrm{As}>\mathrm{Cd}>\mathrm{B}$ $>\mathrm{Hg}$;

- In leaf: $\mathrm{Fe}>\mathrm{Al}>\mathrm{Mn}>\mathrm{Sr}>\mathrm{Zn}>\mathrm{Pb}>\mathrm{Cu}>\mathrm{Cr}>\mathrm{Ni}>\mathrm{Se}>\mathrm{Co}>\mathrm{B}>\mathrm{As}>\mathrm{Cd}$ $>\mathrm{Hg}$.

Declining trend $\mathrm{Fe}>\mathrm{Al}>\mathrm{Mn}>\mathrm{Zn}$ was recorded in rhizome and stem, whereas in the leaf it is: $\mathrm{Fe}>\mathrm{Al}>\mathrm{Mn}>\mathrm{Sr}>\mathrm{Zn}$.

Considering the average values for the contents of metals, bioaccumulation was the greatest in the rhizome of the common reed, and least in the stem. ANOVA revealed difference between various organs of the common reed for the bioaccumulation of metals, using the average contents in them, in total $\mathrm{F}_{(2,9)}=12,34, \mathrm{P}=0,003$. 
Table 4. Serbian limit values and maximum legal concentrations for metals ( $A s, C d$, $\mathrm{Cr}, \mathrm{Cu}, \mathrm{Hg}, \mathrm{Ni}, \mathrm{Pb}$ and $\mathrm{Zn}$ ) (in $\mu \mathrm{g} / \mathrm{g}$ of dry mass) in sediment for each sediment sample, depending on the \% of OM and clay which are defined in the Serbian Regulation of limit values pollutant substances into surface water, groundwater and sediments, and the deadlines for their attaining. LV-limit values. MLC-maximum legal concentration.

\begin{tabular}{|c|c|}
\hline & 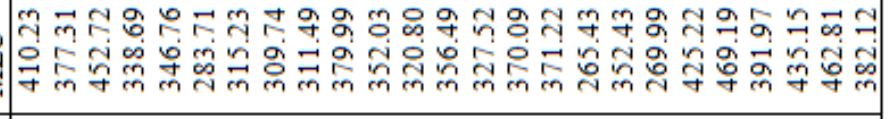 \\
\hline งี & 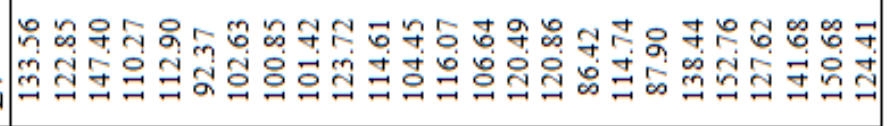 \\
\hline & 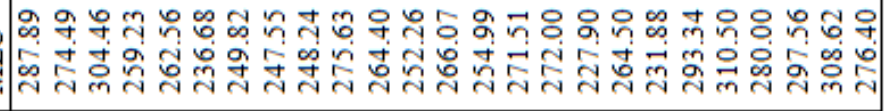 \\
\hline $\bar{\mu}$ & 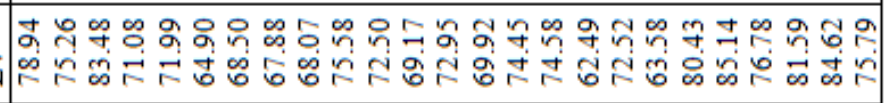 \\
\hline & 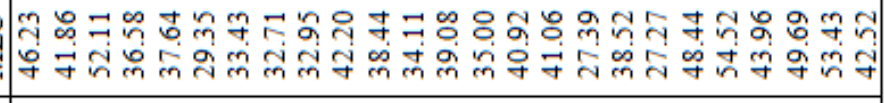 \\
\hline 它 & 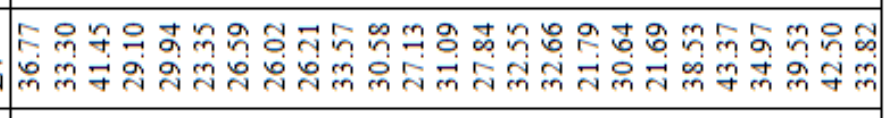 \\
\hline & 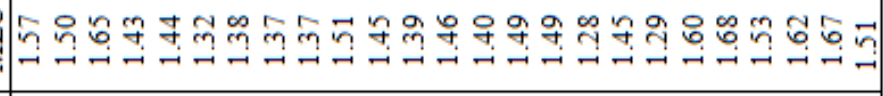 \\
\hline & 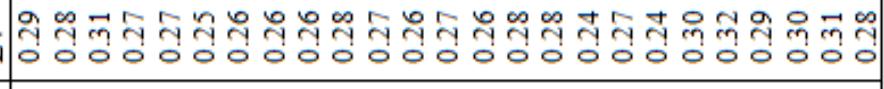 \\
\hline & 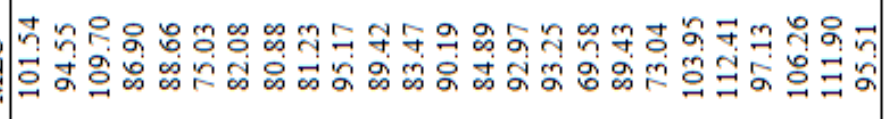 \\
\hline ठี & 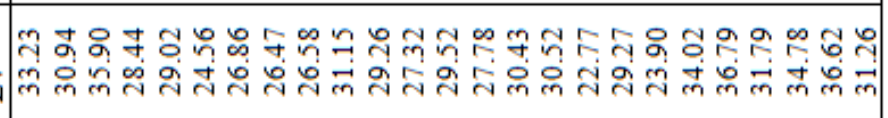 \\
\hline & 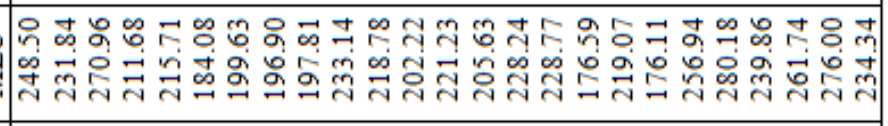 \\
\hline Ü & 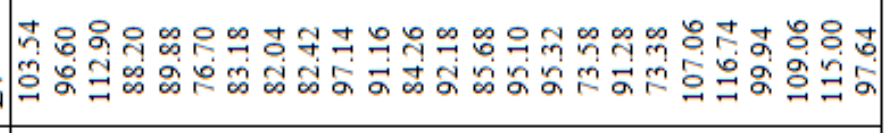 \\
\hline & 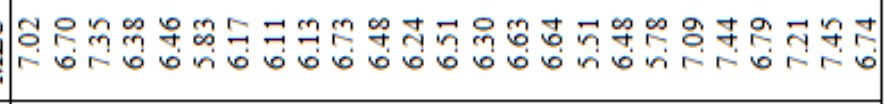 \\
\hline 7 & 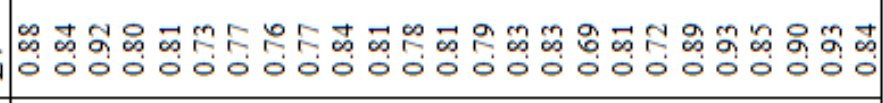 \\
\hline & 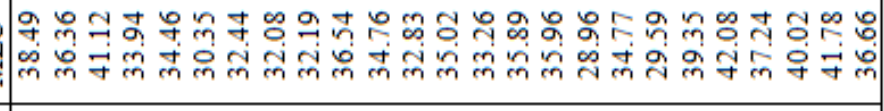 \\
\hline 4 & 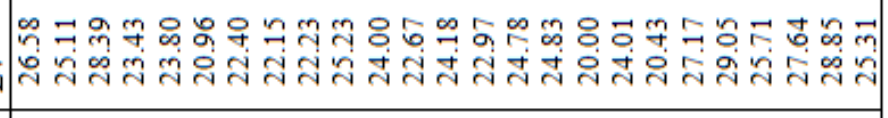 \\
\hline & \\
\hline
\end{tabular}


Table 5. Metal concentrations in rhizome, stem and leaf of common reed at different localities in $\mu \mathrm{g} / \mathrm{g}$ of dry mass.

\begin{tabular}{|l|r|r|r|r|r|r|r|r|r|r|r|r|r|r|r|}
\hline Localities & $\mathbf{A l}$ & $\mathbf{A s}$ & $\mathbf{B}$ & $\mathbf{C d}$ & $\mathbf{C o}$ & $\mathbf{C r}$ & $\mathbf{C u}$ & $\mathbf{F e}$ & $\mathbf{H g}$ & $\mathbf{M n}$ & $\mathbf{N i}$ & $\mathbf{P b}$ & $\mathbf{S e}$ & $\mathbf{S r}$ & $\mathbf{Z n}$ \\
\hline 3 river km-rhizome & 688,68 & 3,27 & 0,00 & 0,54 & 0,00 & 8,68 & 4,74 & 519,17 & 0,11 & 69,75 & 3,42 & 6,34 & 1,44 & 2,86 & 22,05 \\
3 river km-stem & 32,32 & 1,78 & 0,00 & 0,31 & 0,97 & 2,15 & 1,93 & 32,38 & 0,09 & 10,12 & 1,06 & 3,03 & 1,31 & 2,72 & 9,10 \\
3 river km-leaf & 115,22 & 0,98 & 2,10 & 0,35 & 0,89 & 2,81 & 4,34 & 99,21 & 0,09 & 60,31 & 1,17 & 15,69 & 1,61 & 28,12 & 14,38 \\
58 river km- rhizome & 427,66 & 1,52 & 0,00 & 0,59 & 0,49 & 11,94 & 3,65 & 380,02 & 0,09 & 35,68 & 4,59 & 8,27 & 1,20 & 2,66 & 20,28 \\
58 river km-stem & 37,79 & 1,37 & 0,00 & 0,51 & 1,66 & 2,77 & 1,71 & 34,67 & 0,06 & 5,65 & 1,42 & 2,56 & 1,91 & 2,79 & 13,77 \\
58 river km -leaf & 69,60 & 0,61 & 0,17 & 0,34 & 1,09 & 3,29 & 4,42 & 90,12 & 0,10 & 71,63 & 1,43 & 10,89 & 1,32 & 42,61 & 16,66 \\
72 river km-rhizome & 593,55 & 0,53 & 0,00 & 0,57 & 0,30 & 18,27 & 5,26 & 522,50 & 0,08 & 26,01 & 7,57 & 3,56 & 0,98 & 2,91 & 27,93 \\
72 river km-stem & 60,56 & 0,23 & 0,00 & 0,31 & 0,86 & 3,08 & 2,54 & 53,64 & 0,08 & 6,49 & 1,47 & 3,58 & 0,86 & 5,36 & 21,02 \\
72 river km-leaf & 107,33 & 0,00 & 0,39 & 0,38 & 1,09 & 6,49 & 4,83 & 123,09 & 0,11 & 19,52 & 2,02 & 12,33 & 1,09 & 31,94 & 20,08 \\
153 river km-rhizome & 833,99 & 6,56 & 0,13 & 0,86 & 1,42 & 10,66 & 4,18 & 1480,62 & 0,12 & 167,69 & 4,31 & 5,28 & 0,89 & 6,54 & 17,28 \\
153 river km-stem & 38,03 & 0,53 & 0,00 & 0,34 & 1,16 & 2,48 & 1,70 & 57,56 & 0,10 & 37,88 & 1,42 & 2,80 & 0,92 & 8,01 & 17,98 \\
153 river km-leaf & 83,70 & 0,38 & 0,16 & 0,36 & 1,10 & 3,73 & 3,66 & 134,54 & 0,09 & 109,02 & 1,50 & 6,18 & 1,04 & 26,29 & 20,45 \\
\hline
\end{tabular}

The greatest average content of metals in the common reed was recorded at the $153^{\text {rd }}$ river $\mathrm{km}$, and the least at the $58^{\text {th }}$ river $\mathrm{km}$. The greatest accumulation in common reeds at all localities were those of $\mathrm{Al}, \mathrm{Fe}, \mathrm{Mn}, \mathrm{Zn}, \mathrm{Sr}$ i $\mathrm{Pb}$, but certain metals accumulated the most at particular localities, e.g., $\mathrm{Pb}$ at the $3^{\text {rd }}$ river km locality, $\mathrm{Al}, \mathrm{Fe}$ i $\mathrm{Mn}$ at the one at $153^{\text {rd }}$ river $\mathrm{km}$, and $\mathrm{Sr}$ at the $58^{\text {th }}$ river $\mathrm{km}$ locality. ANOVA revealed no difference between localities in the average contents of metals in common reeds either in total $\mathrm{F}_{(3}$, 8) $=0,31, P=0,82$, or for any of the metals.

\section{Bioconcentration Factor (BCF)}

The greatest $B C F$ values were recorded for Se and the lowest for $\mathrm{Al}$ and $\mathrm{Fe}$ (Table б).

Table 6. Biological Concentration Factor.

\begin{tabular}{|l|ccc|c|c|c|c|c|c|c|c|c|c|c|}
\hline \multirow{2}{*}{ Metals } & \multicolumn{3}{|c|}{$\mathbf{3}^{\text {rd }}$ km river flow } & \multicolumn{3}{|c|}{$\mathbf{5 8}^{\text {th }}$ km river flow } & \multicolumn{3}{c|}{$\mathbf{7 2}^{\text {th }}$ km river flow } & \multicolumn{3}{c|}{$\mathbf{1 5 3}^{\text {rd }}$ km river flow } \\
\cline { 2 - 13 } & Rhizome & Stem & Leaf & Rhizome & Stem & Leaf & Rhizome & Stem & Leaf & Rhizome & Stem & Leaf \\
\hline $\mathrm{Al}$ & 0,01 & 0,00 & 0,00 & 0,01 & 0,00 & 0,00 & 0,01 & 0,00 & 0,00 & 0,01 & 0,00 & 0,00 \\
$\mathrm{As}$ & 0,19 & 0,10 & 0,06 & 0,09 & 0,08 & 0,04 & 0,04 & 0,02 & 0,00 & 0,38 & 0,03 & 0,02 \\
$\mathrm{Cd}$ & 0,21 & 0,12 & 0,13 & 0,21 & 0,18 & 0,12 & 0,36 & 0,19 & 0,24 & 0,41 & 0,16 & 0,17 \\
$\mathrm{Co}$ & 0,00 & 0,05 & 0,04 & 0,03 & 0,09 & 0,06 & 0,02 & 0,05 & 0,07 & 0,08 & 0,07 & 0,06 \\
$\mathrm{Cr}$ & 0,07 & 0,02 & 0,02 & 0,09 & 0,02 & 0,03 & 0,14 & 0,02 & 0,05 & 0,09 & 0,02 & 0,03 \\
$\mathrm{Cu}$ & 0,06 & 0,03 & 0,06 & 0,05 & 0,02 & 0,06 & 0,08 & 0,04 & 0,07 & 0,06 & 0,02 & 0,05 \\
$\mathrm{Fe}$ & 0,01 & 0,00 & 0,00 & 0,01 & 0,00 & 0,00 & 0,01 & 0,00 & 0,00 & 0,04 & 0,00 & 0,00 \\
$\mathrm{Hg}$ & 0,31 & 0,25 & 0,25 & 0,33 & 0,22 & 0,37 & 0,47 & 0,47 & 0,65 & 0,40 & 0,33 & 0,30 \\
$\mathrm{Mn}$ & 0,11 & 0,02 & 0,10 & 0,02 & 0,00 & 0,05 & 0,02 & 0,00 & 0,01 & 0,12 & 0,03 & 0,08 \\
$\mathrm{Ni}$ & 0,07 & 0,02 & 0,03 & 0,10 & 0,03 & 0,03 & 0,17 & 0,03 & 0,05 & 0,09 & 0,03 & 0,03 \\
$\mathrm{~Pb}$ & 0,13 & 0,06 & 0,32 & 0,16 & 0,05 & 0,21 & 0,08 & 0,08 & 0,28 & 0,10 & 0,06 & 0,12 \\
$\mathrm{Se}$ & 2,88 & 2,62 & 3,22 & 2,40 & 3,82 & 2,64 & 0,98 & 0,86 & 1,09 & 1,78 & 1,84 & 2,08 \\
$\mathrm{Sr}$ & 0,02 & 0,02 & 0,20 & 0,02 & 0,02 & 0,29 & 0,02 & 0,04 & 0,23 & 0,05 & 0,06 & 0,20 \\
$\mathrm{Zn}$ & 0,07 & 0,03 & 0,05 & 0,06 & 0,04 & 0,05 & 0,10 & 0,07 & 0,07 & 0,05 & 0,05 & 0,06 \\
\hline
\end{tabular}

\section{Pearson's Correlation Coefficient}

All metals we investigated revealed a strong positive correlation between their levels in various organs of common reeds and in the sediment at all localities, except Se, which revealed a negative correlation. 


\section{Translocation ability (TA)}

Translocation ability (TA) forthe majority of metals is of a value mainly less than 1 . It is greater between the rhizome and leaf, than between the rhizome and stem. Co, Sr, $\mathrm{Se}, \mathrm{Hg}, \mathrm{Zn}, \mathrm{Cd}$ and $\mathrm{Pb}$ revealed the greatest $T A$ value between the rhizome and stem, whereas $\mathrm{Sr}, \mathrm{Pb}, \mathrm{Co}, \mathrm{Se}, \mathrm{Hg}$ i Cu revealed the greatest $T A$ value between the rhizome and leaf (Table 7). Generally, $\mathrm{Co}, \mathrm{Sr}, \mathrm{Se}, \mathrm{Pb}$ i Hg were the most mobile metals between the rhizome and both other emerged organs.

Table 7. Translocation ability (TA) between the rhizome and emerged organs of reeds (stem and leaf) for particular metals at all four localities.

\begin{tabular}{|l|r|r|r|}
\hline Metals & Rhizome/sediment & Rhizome/stem & Rhizome/leaf \\
\hline $\mathrm{Al}$ & 0.01 & 0.07 & 0.15 \\
$\mathrm{As}$ & 0.17 & 0.33 & 0.17 \\
$\mathrm{Cd}$ & 0.32 & 0.53 & 0.56 \\
$\mathrm{Co}$ & 0.03 & 2.1 & 1.89 \\
$\mathrm{Cr}$ & 0.10 & 0.21 & 0.33 \\
$\mathrm{Cu}$ & 0.06 & 0.44 & 0.97 \\
$\mathrm{Fe}$ & 0.02 & 0.06 & 0.15 \\
$\mathrm{Hg}$ & 0 & 0.80 & 1 \\
$\mathrm{Mn}$ & 0.06 & 0.20 & 0.87 \\
$\mathrm{Ni}$ & 0.10 & 0.27 & 0.31 \\
$\mathrm{~Pb}$ & 0.12 & 0.51 & 1.92 \\
$\mathrm{Se}$ & 1.13 & 1.11 & 1.12 \\
$\mathrm{Sr}$ & 0.03 & 1.26 & 8.62 \\
$\mathrm{Zn}$ & 0.06 & 0.71 & 0.82 \\
Average values & 0.16 & 0.58 & 1.26 \\
\hline
\end{tabular}

\section{Discussion}

Based on the results obtained, conclusions can be made about the concentrations of the tested metals in the ecosystem of the river Tisza. Contents of metals (in $\mu \mathrm{g} / \mathrm{g}$ of dry mass) in the sediment of the Tisza River bed are given in Table 1. The declining trend of metal concentrations in the sediment is the following: $\mathrm{Al}>\mathrm{Fe}>\mathrm{Mn}>\mathrm{Zn}>\mathrm{Sr}>\mathrm{Cr}>$ $\mathrm{Cu}>\mathrm{Ni}>\mathrm{Pb}>\mathrm{Co}>\mathrm{As}>\mathrm{Cd}>\mathrm{Se}>\mathrm{Hg}$. Al followed by Fe had the highest accumulation values for all sites. This is expected since $\mathrm{Al}$ and $\mathrm{Fe}$ are the most common weathering products. Which correspond to a classical weathering product in research areas where the sediments are mainly composed of $\mathrm{Al}$ and $\mathrm{Fe}$.

In Table 4 are presented Serbian limit values and maximum legal concentrations for metals ( $\mathrm{As}, \mathrm{Cd}, \mathrm{Cr}, \mathrm{Cu}, \mathrm{Hg}, \mathrm{Pb}, \mathrm{Ni}$ and $\mathrm{Zn}$ ) in sediment for each sediment sample, depending on the $\%$ of OM and clay as discussed above. The sediment samples for all sites contained elevated concentrations of $\mathrm{Cd}, \mathrm{Cr}, \mathrm{Cu}, \mathrm{Ni}$ and $\mathrm{Zn}$ with regard to SRLVsS. Concentrations of $\mathrm{Cd}, \mathrm{Cr}, \mathrm{Cu}$ and $\mathrm{Zn}$ are below maximum allowed legal concentration, except $\mathrm{Ni}$ which concentrations are above maximum legal concentration. Research area has a strong agriculture activity and the main metal sources are impurities from fertilizers, pesticides and sewage sludge.

However, the increased concentration of these metals had no significant effect on wildlife of the river Tisza as the determined concentrations of the metals tested in the reed do not exceed the threshold of phytotoxicity (Table 5).

The research proved a strong positive correlation between the concentrations of metals in the sediment and all reed organs (rhizomes, stems and leaves), except Se, 
which revealed a negative correlation. A positive correlation indicates that the value of one variable can be determined when we know the exact value of the other.

Accumulated metals in the common reed are not distributed evenly, but there are target organs for bioaccumulation. The underground organ (rhizome) shows a higher storage capacity than the above ground parts (stems and leaves). Based on many years of research, the tendency of bioaccumulation in plant organs has been established, by which metal concentrations decrease according to the following order: rhizome $>$ leaf $>$ stem (Vymazal et al., 2007; Bonanno and Lo Giudice, 2010), which has been confirmed by the research conducted (Table 5). The concentrations of metals accumulated in the organs of the common reed may vary during the growing season, as a result of a change in the levels of metal concentration in the surrounding medium, and, on the other hand, the changes in their bioavailability (Schierup and Larsen, 1981; Hardej and Ozimek, 2002). All common reed organs show a little $B C F$ for the tested metals. The largest biological accumulation factor was found for selenium, and the lowest for aluminum, mercury, iron and manganese (Table 6). Although aluminum, iron and manganese are present in the highest concentrations in the sediment of the bed of Tisza River and in common reed (Tables 1 and 4), these metals show the smallest BCF (Table 6). The results obtained confirm the earlier assumption that the metals in the sediment originating from the decomposition of rocks are usually connected in the form of chemical compounds that are not easily bioavailable to wildlife (Schropp et al., 1990).

Examining the effect of the site on the bioaccumulation of metals in the common reed, it was found that most metals accumulate on the $153^{\text {rd }} \mathrm{km}$ of the river flow, but the effect of the site on the bioaccumulation of metals in the investigated area has no statistical significance. The results can be explained by the fact that the concentrations of metals in sediments along the entire flow of the river Tisza are generally consistent.

The concentration of aluminum in the common reed (Table 5) is below the threshold of phytotoxicity, which according to Kabat-Pendias (2001) is $1000-3000 \mu \mathrm{g} / \mathrm{g}$. The $B C F$ of aluminum in the common reed was the lowest (Table 6). Metals in sediments originating from the decomposition of rocks, such as aluminum and iron are usually connected in the form of chemical compounds that are not easily bioavailable to wildlife. Aluminium is mainly accumulated in the rhizome of the common reed and possesses low mobility to aboveground organs $(T A<0.2)$, which is consistent with the previous studies showing that aluminum and iron mainly accumulate in the root of metallophyte (Baker et al., 1994) (Table 7).

The values obtained for arsenic in the sediment of the bed of the river Tisza (3.8-19 $\mu \mathrm{g} / \mathrm{g})$ (Table 1) are below the values wich prescribed SRLVsS (Table 4). Data relating to the bioaccumulation of arsenic in the river is little known. Aquatic organisms adopt arsenic directly from the water or through the food chain. It accumulates in primary producers (plants and algae), but its concentration does not increase when invertebrates and fish (consumers) are concerned (Štajn et al., 2007).

The content of cadmium in the sediment of the river Tisza $(0.2-2.8 \mu \mathrm{g} / \mathrm{g})($ Table 1$)$ increased compared to values wich prescribed SRLVsS (Table 4), while the concentration of cadmium in rhizome, leaves and stems of the reed are significantly lower than the phytotoxic range $(5-100 \mu \mathrm{g} / \mathrm{g})$ which is suggested by Chaney (1989). According to Allen (1989), the concentrations of cadmium in the plant in an unpolluted environment ranges from $0.01-0.3 \mu \mathrm{g} / \mathrm{g}$, which approximately corresponds to the values obtained in this study (Table 5). The $B C F$ of cadmium in rhizome, stem and leaves is $<$ 1. Cadmium is a highly toxic, non-essential element that affects the growth, metabolism 
and regime of water in a plant (Divan et al., 2009). One reason is the high toxicity of its interaction with other elements. In addition to toxicity, oxidative stress is caused by releasing free radicals which causes the damage to the membrane lipids, proteins, pigments and nucleic acids (Hernandez et al., 1998). P. Australis is a cadmium tolerant species, whose defense strategy is based on the increased activity of antioxidant enzymes (Ederli et al., 2004).

Cobalt concentrations in the rhizomes, stems and leaves of the reed are far lower than the phytotoxic range $(15-50 \mu \mathrm{g} / \mathrm{g})$ which is suggested by Kabat-Pendian (2001). Plants on average acquire small amounts of cobalt, $B C F$ is low (Table 6). Acquired over the roots by a transpiration stream, it is transported to the aboveground organs where it is accumulated in the peripheral part and the top of the leaf, and it is accumulated in a greater amount in generative than in vegetative organs (Kastori, 1983). The transfer factor for cobalt between the rhizomes and stems and leaves of the common reed is $>1$ (Table 7). Plants can acquire cobalt through leaves. It is a regular ingredient in plant cells. Its role in life processes is not well known, but it is emphasized in the symbiotic fixation of atmospheric nitrogen and the oxidation processes.

Chromium content in the sediment of the river Tisza $(116.3-136.8 \mu \mathrm{g} / \mathrm{g})($ Table 1$)$ was higher than the values wich prescribed SRLVsS (Table 4), and the concentration of chromium in the common reed rhizome (Table 5) is higher than the threshold of phytotoxicity $(0.5 \mu \mathrm{g} / \mathrm{g})$, which is given by Allen (1989). For plants, chromium is not an essential element, it belongs to the group of elements that are harmful, and plants do not accumulate it in great amounts. It is believed that those plants that have the ability to accumulate iron, accumulate chromium as well (Kastori, 1995).

Copper concentration in the sediment of the river Tisza $(25.6-88.9 \mu \mathrm{g} / \mathrm{g})($ Table 1$)$ is higher than the values wich prescribed SRLVsS (Table 4), while the value of the copper in the common reed is below the threshold of phytotoxicity $(25-40 \mu \mathrm{g} / \mathrm{g}$ ), according to Chaney (1989). Siedlecka et al. (2001) found a tendency to accumulate copper in the roots with very little mobility to the aboveground organs. Thus, it was pointed out that the roots behaved as filters, since the concentrations of copper found in the plant were $70 \%$ less than the concentrations determined in the root (Siedlecka et al., 2001). However, the concentrations of copper in this study show the same values in the rhizome and the leaf (Table 5). Kastori (1995) explains this phenomenon saying that plants can acquire copper ions over the leaf surface. Otherwise, copper shows a low potential to bioaccumulate itself in plants and there is no evident biomagnification. Ascending copper transport as well as its redistribution is highly dependent on the level of the plant's copper supply. It is one of the essential elements needed for the various enzymatic activities of plants.

Concentrations of iron found in the common reed (Table 5) were below the threshold of toxicity, ranging from 1000 to $3000 \mu \mathrm{g} / \mathrm{g}$ (Kabata-Pendian, 2001). Similar to aluminum, iron has a low $B C F$ because in the sediment it originates from the decomposition of rocks, and it is not easly bioavailable to the wildlife of aquatic ecosystems (Table 6). According to the research of Szymanowska et al. (1999) the iron content in the sediment is linearly correlated to its presence in the plant organs (Szymanowska et al., 1999), and roots show very high values, while mobility through the tissues of $P$. australis is low (Bonanno, 2011), which was confirmed in this study (Table 7).

Values for mercury in the sediment of the bed of the river Tisza $(0.11$ to $0.36 \mu \mathrm{g} / \mathrm{g})$ (Table 1) are below the values wich prescribed SRLVsS (Table 4). Data relating to the 
bioaccumulation of mercury in the river is little known. Different studies have shown that the roots of various aquatic macrophytes accumulate higher concentrations of mercury than other plant parts, e.g. the amount of mercury accumulated in the roots of Eichhornia crassipes is 2-3 times higher than in shoots (Jana, 1988), which is not in accordance with the results obtained. Mercury concentrations in rhyzome, stem and a leaf of the common reed share approximately equal values (Table 5).

The content of manganese in the common reed (Table 5) was below the threshold of toxicity for plants which is $50-500 \mu \mathrm{g} / \mathrm{g}$ according to Allen (1989). The mechanism of uptake of manganese is specific. During the first phase, it is absorbed into the root surface, actually the apparent free space of the root, and then, depending on the metabolic processes inside the cell, it is activelly transferred. In this regard the dynamics of accumulation of manganese in the plants during the growing season has its own distinctive flow and depends on a number of internal and external factors. The movement of manganese is especially fast towards the meristem tissue and reproductive organs, thus younger plant organs, whoseh metabolic processes are more intensive, are usually richer in manganese than older plants ( $T A$ between the stem and leaves is $\approx 1$ ) (Table 7).

The obtained values for nickel in the sediment of the river Tisza $(38.4-53.7 \mu \mathrm{g} / \mathrm{g})$ (Table 1) were higher than the values wich prescribed SRLVsS (Table 4), and only the concentration determined in the reed rhizome can be considered dangerous for the plant (Table 5). According to Allen (1989), nickel concentrations above $5 \mu \mathrm{g} / \mathrm{g}$ are considered phytotoxic. Recently, nickel was recognised as one of the necessary elements for higher plants, because it was determined that it represents a component of enzymes important for normal life processes. Low concentrations of nickel are essential for plants, but at higher concentrations its toxic effects have been proved (Parida et al., 2003; Demirezen et al., 2007). The intensity of uptake of nickel, and its accumulation in plants under natural conditions depends on its concentration in the environment as well as on the $\mathrm{pH}$ value of the environment.

The lead content in the sediment of the river Tisza $(13.6-56 \mu \mathrm{g} / \mathrm{g})($ Table 1) was lower than the values wich prescribed SRLVsS (Table 4), while the concentration of lead in the common reed (Table 5) was far smaller than the phytotoxic range which is 30-300 $\mu \mathrm{g} / \mathrm{g}$ (Roos, 1994). The concentrations found in the leaves are, on average, greater than the value determined in the rhizomes and stems (Table 5), which can be explained by the fact that the leaves accumulate lead by deposition from the air, which directly affects aboveground organs, as well as the values of TA (Table 7). TA between the stem and leaves is $>1$. Once it gets into the leaves, lead can be returned to the environment either directly, through secretion from the leaves (Burke et al., 2000; Batty and Younger, 2004, Weis et al., 2004) or indirectly by decay which thereby increases its bioavailability.

The values obtained for selenium in the common reed are higher than those in the sediment (Table 1 and 5). Selenium is the only metal that shows a negative linear correlation between the concentrations in the common reed and the sediment, as well as the largest $B C F$ (Table 6). $T A$ for selenium between all common reed organs is higher than 1 , which confirms the equal representation of this metal in the common reed (Table 7). Selenium is a very important micronutrient, necessary for the proper functioning of the enzyme systems, and therefore it is expected to be adopted in a larger amount.

The values obtained for strontium (Table 5) in the common reed are below the threshold of phytotoxicity which is $1000 \mu \mathrm{g} / \mathrm{g}$ according to Kabat-Pendias (2001). The 
high ratio of rhizome / leaf TA shows the interesting mobility of this element (Table 7). Thus, by doing this research, we have found out that the largest concentration of strontium is determined exactly in the highest parts of the plant, which is in accordance with Kabat-Pendias (2001).

The concentrations of zinc in the sediment of the river Tisza's bed $(76-364 \mu \mathrm{g} / \mathrm{g})$ (Table 1) were higher than the values wich prescribed SRLVsS (Table 4), while the concentration of zinc in the common reed (Table 5) is below the threshold of phytotoxicity which is $500-1500 \mu \mathrm{g} / \mathrm{g}$ as proposed by Chaney (1989). So far, works published concerning the distribution of zinc in the plant's tissue are generally not the same, sometimes they are even contradictory. Since zinc is an essential element it can be found in all organs and tissues of plants. On the basis of the published results regarding the distribution of zinc in plants, it can be concluded that it is accumulated to a greater extent in the roots and leaves (Kastori, 1990), which was confirmed by the survey (Table 5). As for translocation, zinc belongs to the group of elements whose mobility in plants is not great (Table 7).

\section{Conclusions}

On the basis of the research the following conclusions can be drawn:

a) The sediment samples for all sites contained elevated concentrations of $\mathrm{Cd}, \mathrm{Cr}$, $\mathrm{Cu}, \mathrm{Ni}$ and $\mathrm{Zn}$. Concentrations of $\mathrm{Cd}, \mathrm{Cr}, \mathrm{Cu}$ and $\mathrm{Zn}$ are below maximum legal concentration, except $\mathrm{Ni}$ which values are above maximum legal concentration based on the Serbian Regulation of limit values pollutant substances into surface water, groundwater and sediments, and the deadlines for their attaining, but without impact on wildlife because the established concentrations of metals in the common reed do not cross the threshold of phytotoxicity;

b) The common reed is a good indicator of the condition of the environment because a stron positive correlation was found between the concentrations of metals in the sediment and all reed organs (rhizomes, stems and leaves);

c) Accumulated metals in the common reed are not distributed evenly, the underground organ (rhizome) shows a higher storage capacity than the above ground parts (stems and leaves);

d) Due to the uniform concentration of metals in the ecosystem (biotope and biocenosis) of the Tisza, there are no differences in bioaccumulation in different localities.

Acknowledgements. Research was supported by Grants 173025, 176006 and 176019 of the Ministry of Education and Science of the Republic of Serbia.

\section{REFERENCES}

[1] Agbaba, J., Ugarčina, S., Tričković, J., Dalmacija M. (2008): Toksične supstance i njihov efekat, Zagađujuće materije u vodenom ekosistemu i remedijacioni procesi. - Prirodnomatematički fakultet, Departman za hemiju, Novi Sad.

[2] Allen, S.E. (1989): Chemical Analysis of Ecological Material. - Blackwell Scientific Publications, Oxford. 
[3] Baker, A.J.M., Reeves, R.D., Hajar, A.S. (1994): Heavy metal accumulation and tolerance in British populations of the metallophytes Thlaspi caerulescens J. \& C. Presl (Brassicaceae). - New Phytol. 127: 61-68.

[4] Balanson, S., Mal, T. (2005): Macrophytes as biomonitors of trace metals. - In: Lehr, J. (ed.) Water Encyclopedia: Water Quality and Resource Development, Hoboken: John Wiley and Sons Inc.

[5] Batty, L.C., Younger, P.L. (2004): Growth of Phragmites australis (Cav.) Trinex. Steudel in mine water treatment wetlands: effects of metal and nutrient uptake. - Environ. Pollut. 132: 85-93

[6] Bishop, P.L., De Waters, J. (1988): Biotechnology for Degradation of Toxic Chemicals in Hazardous Wastes. - Noyes Data Corp., Park Ridge, NJ.

[7] Bonanno, G., La Giudice R. (2010): Heavy metal bioaccumulation by the organs of Phragmites australis (common reed) and their potential use as contamination indicators. - Ecolo. Indica. 10: 639-645.

[8] Bonanno, G. Trace element accumulation and distribution in the organs of Phragmites australis (common reed) an biomonitoring applications. - Ecotoxi. and Environ. Safe., (in press), DOI:10.1016/j.ecoenv.2011.01.018

[9] Borišev, M., Stanković, Ž. (2006): Makrofite Tise kao pokazatelj nutritivnog opterećenja. - In: Pavić, D., Đorđević, A., Suđi, I., Milić-Đorđević, V., Vukov, D., Igić R. (eds.) Ekološko istraživanje Tisa 2005, Tiski cvet, Novi Sad.

[10] Bragato, C., Brix, H., Malagoli, M. (2009): Accumulation of nutrients and heavy metals in Phragmites australis (Cav.) Trin. ex Steudel and Bolboschoenus maritimus (L.) Palla in a constructed wetland of the Venice lagoon watershed. - Environ. Pollut. 144: 967-975

[11] Burke, D.J., Weis, J.S., Weis, P. (2000): Release of metals by the leaves of the salt marsh grasses Spartina alterniflora and Phragmites australis. - Estuar. Coast. Shelf Sci. 51: $153-159$.

[12] Chaney, R.L. (1989): Toxic element accumulation in soils and crops: protecting soil fertility and agricultural food chains. - In: Bar-Yosef, B., Barrow, N.J., Goldshmid, J. (eds.) Inorganic Contaminants in the Vadose Zone, Springer-Verlag, Berlin.

[13] Demirezen, D., Aksoy, A., Uruc, K. (2007): Effect of population density on growth, biomass and nickel accumulation capacity of Lemna gibba (Lemnaceae). - Chemo. 66: 553-557.

[14] Divan, Jr. A.M., De Oliveira, P.L., Perry, C.T., Atz, V.L., Azzarini-Rostirola, L.N., RayaRodriguez, M.T. (2009): Using wild plant species as indicators for the accumulation of emissions from a thermal power plant, Candiota, South Brazil. - Ecol. Indic. 9: 11561162 .

[15] Duman, F., Cicek, M., Sezen, G. (2007): Seasonal changes of metal accumulation and distribution in common club rush (Schoenoplectus lacustris) and common reed (Phragmites australis). - Ecotoxi. 16: 457-463.

[16] Ederli, L., Reale, L., Ferranti, F., Pasqualini, S. (2004): Responses induced by high concentration of cadmium in Phragmites australis roots. - Physiol. Plantarum 121: 66-74

[17] Gakwavu, R.J., Sekomo, B.C., Nhapi, I. (2012): Zinc and chromium removal mechanisms from Industrial wastewater by water hyacinth, Eichhornia crassipes (mart.) Solms. Applied ecology and environmental research 10(4): 493-502.

[18] Gerloff, G.C., Krombholz, P.H. (1966): Tissue analysis as a measure of nutrient availability for the growth of aquatic plants. - Limnol. Oceanogr. 11: 529-537.

[19] Hardej, M., Ozimek, T. (2002): The effect of sewage sludge flooding on growth and morphometric parameters of Phragmites australis (Cav.) Trin. ex Steudel. - Ecol. Eng. 18: $343-350$.

[20] Hernandez, L.E., Lozano, E., Garate, A., Carpena, R. (1998): Influence of cadmium on the uptake, tissue accumulation and subcellular distribution of manganese in pea seedlings. - Plant Sci. 132: 139-151. 
[21] Jana, S. (1988): Accumulation of $\mathrm{Hg}$ and $\mathrm{Cr}$ by three aquatic species and subsequent changes in several physiological and biochemical plant parameters. - Water Air Soil Pollut. 38: 105-109.

[22] Kabata-Pendias, A. (2001): Trace Elements in Soils and Plants. - CRC Press, Boca Raton.

[23] Kastori, R. (1983): Uloga elemenata u ishrani biljaka. - Matica srpska, Novi Sad.

[24] Kastori, R. (1990): Neophodni mikroelementi, fiziološka uloga i značaj u biljnoj proizvodnji. - Naučna knjiga, Beograd.

[25] Kastori, R. (1995): Zaštita agroekosistema, Novi Sad.

[26] Kastori, R., Petrović, N., Maksimović-Arsenijević, I. (1997): Teški metali i biljke. - In: Kastori, R. (ed.), Teški metali u životnoj sredini, Naučni institut za ratarstvo i povrtarstvo, Novi Sad.

[27] Lesage, E., Rousseau, D.P.L., Meers, E., Tack, F.M.G., De Pauw, N. (2007): Accumulation of metals in a horizontal subsurface flow constructed wetland treating domestic wastewater in Flanders, Belgium. - Sci. Total Environ. 380: 102-115.

[28] Levine, S.N., Rudnick, D.T., Kelly, J.R., Morton, R.D., Buttel, L.A. (1990): Pollution dynamics as influenced by seagrass beds: experiments with tributyltin in Thalassia microcosms. - Mar. Environ. Res. 30: 297-322.

[29] Olivares-Rieunont, S., Lima, L., De la Rosa, D., Graham, W., Columbie, I., Santana, J. (2007): Water hyacinthes (Eichhornia crassipes) as indicators of heavy metal impact of a large landfill on the Almendares river near Havana, Cuba. - Bull. of Environ. Contami. and Toxico. 79: 583-587.

[30] Pajević, S., Vučković, M., Stanković, Ž., Krstić, B., Kevrešan, Ž., Radulović, S. (2002): The content of some macronutrient and heavy metals in aquatic macrophytes of three ecosystems connected to the Danube in Yugoslavia. - Arch. fur Hydrobio. Suppl. 141: 73-83.

[31] Pall, K., Rath, B., Janauer, G.A. (1996): Die Makrophyten in dynamischen und abgedammten Gewassersysteman der Kleinen Dchuttinsel (Donau-Flub-km 1848 bis 1806) in Ungarn (The macrophyte vegetation of the Szigrtkon flood plain waters, Hungary, river-km 1848-1806). - Limnolo. 26: 63-78.

[32] Parida, B., Chhibba, I., Nayyar, V. (2003): Influence of nickel-contaminated soils on fenugreek (Trigonella corniculata L.) growth and mineral composition. Scie. Horticu. 98: 113-119.

[33] Peverly, J.H., Surface, J.M., Wang, T. (1995): Growth and trace metal absorption by Phragmites australis in wetlands constructed for landfill leachate treatment. - Ecolo. Enginee. 5: 21-35.

[34] Ravera, O. (2001): Monitoring of the aquatic environment by species accumulator of pollutants. - In: Ravera, O. (ed.) Scientific and legal aspects of biological monitoring in freshwater J. Limnol.

[35] Roos, M.S. (1994): Sources and forms of potentially toxic metals in soil-plant systems. In: Ross, M.S. (ed.) Toxic Metals in Soil-Plant System, John Wiley, Chichester.

[36] Serbian Regulation of limit values pollutant substances into surface water, groundwater and sediments and the deadlines for their attaining. ("Off. Gazette of RS" no. 50/12).

[37] Schierup, H.H., Larsen, V.J. (1981): Macrophyte cycling of zinc, copper, lead and cadmium in the littoral zone of a polluted and non-polluted lake, I. Availability, uptake and translocation of heavy metals in Phragmites australis (Cav.) Trin. - Aquat. Bot. 11: 197-210.

[38] Schropp, S.J., Lewis, F.G., Windom, H.L., Ryan, J.D., Calder, F.D., Burney, L.C. (1990): Interpretation of metal concentrations in estuarine sediments of Florida using aluminium as a reference element, Estuaries. - Estua. and Coas. 13: 227-235.

[39] Stanković, Ž., Pajević, S., Vučković, M., Stojanović, S. (2000): Concentrations of trace metals in dominant aquatic plants of Lake Provala (Vojvodina, Yugoslavia). - Biolo. Plant. 43: 583-585. 
[40] Siedlecka, A., Tukendorf, A., Skorzynska-Polit, E., Maksymiec, W., Wojcik, M., Baszynski, T. (2001): Angiosperms (Asteraceae, Convolvulaceae, Fabaceae and Poaceae; other than Brassicaceae). - In: Prasad, M.N.V. (ed.) Metals in the Environment Analysis by Biodiversity Marcel Dekker, Inc., New York.

[41] Štajn, A., Žikić, R., Saičić, Z. (2007): Ekofiziologija i ekotoksikologija životinja. Prirodno-matnematički fakultet, Kragujevac.

[42] Szymanowska, A., Samecka-Cymerman, A., Kempers, A.J. (1999): Heavy metals in three lakes in West Poland, Ecotoxicol. Environ. Saf. 43: 21-29.

[43] Vymazal, J., Svehla, J., Kropfelova, L., Chrastny, V. (2007): Trace metals in Phragmites australis and Phalaris arundinacea growing in constructed and natural wetlands. - Sci. Total Environ. 380: 154-162.

[44] Wang, W., Gorsuch, J.W., Hughes, J.S. (1997): Plants for Environmental Studies. - CRC Press, New York.

[45] Ward, T.J. (1987): Temporal variation of metals in the seagrass Posidonia australis and its potential as a sentinel accumulator near a lead smelter. - Mar. Biol. 95: 315-321.

[46] Weis, J.S., Glover, T., Weis, P. (2004): Interactions of metals affect their distribution in tissues of Phragmites australis. - Environ.Pollut. 131: 409-415.

[47] Welsh, R.P.F., Denny, P. (1980): The uptake of lead and copper by submerged aquatic macrophytes in two English lakes. - J. Ecol. 68: 443-455.

[48] Westlake, D.F. (1975): Primary production of freshwater macrophytes. - In: Cooper, J.P. (ed.) Photosyntesis and Productivity in Different Environments, Cambridge University Press, Great Britani.

[49] Zwolsman, J.J.G., Berger, G.W., Van Eck, G.T.M. (1993): Sediment accumulation rates, historical input, post depositional mobility and retention of major elements and trace metals in salt marsh sediments of the Scheldt estuary, SW Netherlands. - Mar. Chem. 44: 73-94. 